\title{
Effect of Bacillus thuringiensis kurstaki on mid-gut structure of the beet web moth, Spoladea recurvalis F. larvae (Lepidoptera: Crambidae) reared on semi-synthetic diet
}

\author{
Monir M. M. El Husseini(i)
}

\begin{abstract}
Larvae of the beet web moth, Spoladea recurvalis F. (Lepidoptera: Crambidae), were reared on a semi-synthetic diet under laboratory temperature of $25^{\circ} \mathrm{C}$. The microbial bioinsecticide Dipel 2X (Bacillus thuringiensis kurstaki) was bioassayed versus the 2 nd instar larvae $\left(L_{2}\right)$ of $S$. recurvalis by mixing in the semi-synthetic diet at different concentrations $(5,2.5,1.25 ; 0.6$ and $0.3 \% \mathrm{w} / \mathrm{w})$. The concentration $1.25 \%$ of Dipel $2 \mathrm{X}$ mixed in the semi-synthetic diet was fed to larvae $\left(L_{2}\right)$ to prolong the pre-death period for 5 days in order to follow its effect on the structure of mid-gut. Treated larvae as well as those of the control were fixed in Bouin's fixative at 1, 2, 3, 4, and 5 days post treatment and processed for paraffin serial sectioning at 6-8 $\mu \mathrm{m}$ with double staining by eosin and hematoxylin. Cross sections in the mid-gut were examined with a light microscope in both treated larvae and those of the control. The gradual alterations in mid-gut structure till death of the treated larvae were described.
\end{abstract}

Keywords: Bacillus thuringiensis, Spoladea recurvalis, Mid-gut structure, Semi-synthetic diet

\section{Background}

The beet web moth, Spoladea recurvalis F. (Lepidoptera: Crambidae), is a polyphagous cosmopolitan species inhabiting most states of USA, the Neotropics, and many of the warmer regions of the world in Australia, Africa, and Southeast Asia. Figueroa et al. (2005) recorded the larvae feeding on leaves of weeds, e.g.; horse purslane (Trianthema portulacastrum); common pigweed (Amaranthus dubius Mart.); botoncillo (Borreria ocymoides); and on economic crops like sugar beet (Beta vulgaris var. saccharifera), sweet cherry pepper (Capsicum frutescens), tomato (Lycopersicon esculentum), cucumber (Cucumis sativus), and aubergine (Solanum melongena). They feed also on mangold (Beta vulgaris var. vulgaris), chard (Beta vulgaris), spinach (Spinacia oleracea), okra (Abelmoschus esculentus), cotton (Gossypium barbadens), maize (Zea mays), soybeen (Glycine max), various weeds of Chenopodium spp., and other economic crops. Host range and

Correspondence: monir.elhusseini@agr.cu.edu.eg;

monirelhusseini45@gmail.com

Centre of Biological Control, Faculty of Agriculture, Cairo University, Cairo, Egypt

Springer Open damage of $S$. recurvalis on leafy amaranth (Amaranthus spp.) and Solanum scabrum were discussed by Mureithi et al. (2017). As defoliators, the larvae feed on the underside tissues of the leaves; meanwhile, they produce a slight web cover of silk under which they remain somewhat protected on site (Sithanantham et al. 2003).

In Egypt, the control of sugar beet insect pests relies on insecticides applied mostly on a regular basis (usually every 10 to 15 days) during the sugar beet growing season. These include ecdysone agonists (e.g., tebufenozide), the novel mode of action biocide metabolite of Streptomyces avermitilis (e.g., emamectin benzoate), or of Saccharopolyspora spinosa (e.g., spinosyns), and extracts from the neem, Azadirachta indica or other chemical pesticides recommended by Agricultural $\mathrm{Au}$ thorities in the country. To overcome the undesired known side effects of the chemical insecticides, new approaches in pest management including biological control agents are developed. Microbial control of insect pests is a promising trend due to its high specificity and environmental safety (El Husseini 2006; El Husseini et al. 2008). 
Aim of the present work is to study the effect of Dipel 2X (Bacillus thuringiensis subsp. kurstaki) on larvae of the beet web moth $S$. recurvalis under laboratory conditions and its effect on their midgut structure.

\section{Materials and methods}

Rearing larvae of $S$. recurvalis on semi-synthetic diet

The colony started with larvae collected from sugar beet fields in Sakha at Kafr El Sheikh Governorate, Egypt and transferred to the laboratory at the Faculty of Agriculture, Cairo University, Giza Governorate. They were reared on daily fresh sugar beet leaves until pupation took place. Pupae were placed in egg-laying cages of cylindrical glass (19 $\mathrm{cm}$ in diameter and $20 \mathrm{~cm}$ in height), furnished with tissue paper, and bottomed and topped with plastic plates ( $20 \mathrm{~cm}$ in diameter and $3 \mathrm{~cm}$ in height). The bottom plate was provided with a small cap $(3 \mathrm{~cm}$ in diameter), provided with a 1:15 solution of bee honey:water, as food for the emerged moths. Eggs were collected from the tissue paper by cutting and placed in Petri-dishes until hatching.

Newly hatched larvae were reared till pupation on a semi-synthetic diet formulated according to Shorey and Hall (1965). The diet was composed of $500 \mathrm{ml}$ distilled water, $9.9 \mathrm{~g}$ agar, $12.5 \mathrm{~g}$ yeast, $3.7 \mathrm{mg}$ vitamin B-complex, $1.9 \mathrm{~g}$ nepagin, $0.5 \mathrm{~g}$ sorbic acid, and $60 \mathrm{~g}$ matched cocked beans (Phaseolus vulgaris). The agar was added gradually to the distilled water under continuous stirring in boiling water bath for $40 \mathrm{~min}$. With the exception of sorbic acid, all the components were then mixed with the agar in the hot water bath for another $30 \mathrm{~min}$. Thereafter, the mixture was left to cool down to about $45^{\circ} \mathrm{C}$. Then, the sorbic acid was added, also under stirring. The prepared diet was poured into sterile plastic plates $(15 \mathrm{~cm}$ in diameter and 5 $\mathrm{cm}$ in height) in a 2-cm-thick diet layer and left to cool. Diet plates were secured by polyethylene covers, fitted in place by rubber band to avoid dryness, and kept in the refrigerator until needed.

The rearing plates were covered by their top plates like Petri-dishes and incubated at $25{ }^{\circ} \mathrm{C}$. The developing larvae produced a slight silky web cover on the diet under, which they feed on. As mining in the published literature, this could be the first trial to rear the beet web larvae on semisynthetic diet (Fig. 1). Surplus diet was added to the developing larvae when needed till pupation took place. Pupae were collected and kept in similar egg laying containers till moth's emergence, copulation, and egg laying.

For standardization of the $\mathrm{L}_{2}$ larvae for the bioassay test, reared larvae of the $\mathrm{L}_{1}$ that reached the moulting stage with the characteristic erected head capsule, swollen cervicum, and remaining motionless were gently transferred by a wetted fine camel-hair brush onto the treated diet. Within $12 \mathrm{~h}$, they moult into the 2 nd instar $\left(\mathrm{L}_{2}\right)$ and after a short while, they started feeding on the treated or untreated (control) diet.

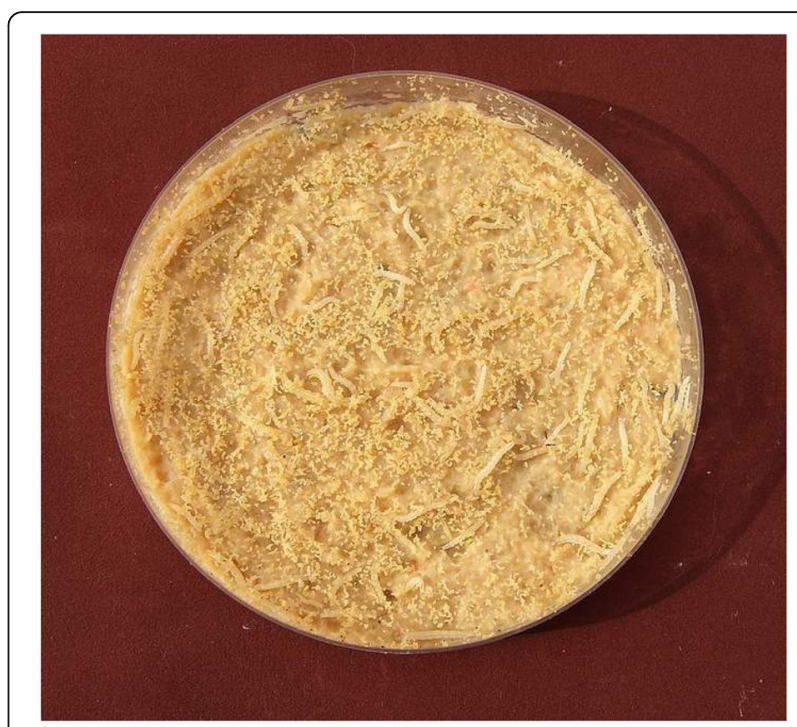

Fig. 1. Larvae of S. recurvalis reared on semi-synthetic diet showing the silky web cover

\section{Tested Bacillus thuringiensis}

The commercial formulation Dipel 2X-wettable powder based on Bacillus thuringiensis subsp. kurstaki (B.t.k.) (Abbott Laboratories. Illinois, Chicago, USA) was used to treat the larvae of $S$. recurvalis $\left(\mathrm{L}_{2}\right)$ by mixing the B.t.k. formulation into the semi-synthetic diet. The formulation contains 32,000 international unit of potency per mg measured on Galleria mellonella L. and 1452 billion IU/pound representing $6.4 \%$ as active ingredient (spore-endotoxin-complex) and 83.6\% inert ingredients.

\section{Bioassay test}

Five grams of Dipel 2X were mixed into $95 \mathrm{~g}$ of the semisynthetic diet to prepare a diet containing $5 \%$ concentration of the commercial B.t.k. formulation. Successive concentrations $(5.0,2.5,1.25,0.6$, and $0.3 \%)$ were prepared by mixing them with the diet. Then, 500 larvae $\left(\mathrm{L}_{2}\right)$ were left to feed each of 100 ones on the tested diet (concentration) for 24 $\mathrm{h}$, devided into four replicates, each of 25 larvae. Thereafter, larvae fed on each concentration were transferred onto untreated diet and mortality rate was recorded daily for 1 week post treatment. One hundred larvae $\left(\mathrm{L}_{2}\right)$ in four replicates each of 25 ones were reared on untreated diet and served as control. The test was carried out in the laboratory under incubation at $25^{\circ} \mathrm{C}$.

\section{Histopathology}

The B.t.k.-treated diet (concentration 1.25\%), on which the larval mortality reached $100 \%$ on the fifth day post treatment estimated through the bioassay test, was used for feeding 50 larvae $\left(\mathrm{L}_{2}\right)$ of $S$. recurvalis to obtain a slow killing time facilitating the daily histopathological, follow the induced changes in the structure of the mid-gut (El 
Husseini 1976; Omar 2004). Five larvae from those fed on the treated diet and five others from the control (reared on untreated diet) were fixed daily in Bouin's alcohol fixative during the next successive 5 days after treatment. Fixation process lasted $16 \mathrm{~h}$; thereafter, larvae were processed in the common way for preparing paraffin serial sections of 6-8 $\mu \mathrm{m}$ with a double staining by eosin and hematoxylin; followed by mounting in Canada Balsam as permanent preparations (El Husseini 1980). Prepared cross sections in the mid-gut were examined with a light microscope in both treated larvae and those of the control. A Leica camera fixed to the microscope and connected to a PC served in shooting the needed photos.

\section{Results and discussion Bioassay}

Results in Table 1 showed that the 100\% mortality among larvae of $\mathrm{L}_{2}$ fed on diet mixed with different concentrations of the commercial B.t.k (Dipel 2X) was reported on the 3rd, 4th, and 5th day post treatment for the diet with the B.t.k. concentrations of $5,2.5$, and $1.25 \%$, respectively. Meanwhile, diet with the concentrations 0.6 and $0.3 \%$ resulted to 92 and $86 \%$ mortality, respectively on the 7 th day post treatment. These results for increased larval mortality of S. recurvalis by increasing the doses of B.t.k. are in line with this trend in all susceptible lepidopteran larvae (Dimitriadis and Domouhtsidou 1996; El Husseini 1976; El Husseini et al. 2012; El Husseini 2015; Reda et al. 2016).

\section{Histopathological effect of B.t.k. on mid-gut of S. recurvalis}

Cross sections in mid-gut of untreated (control) larvae of S. recurvalis (Fig. 2a) showed the epithelial cells (ep) in the classical normal architecture surrounded by the basement membrane $(\mathrm{bm})$, circular $(\mathrm{cm})$, and longitudinal muscles $(\mathrm{lm})$. The peritrophic membrane $(\mathrm{pm})$ secreted by the specialized epithelial cells was well-defined. According to the position of tissues during the sectioning, the brush border membrane of the epithelial cells could be easily identified at different locations of the mid-gut. In case of feeding on

Table 1 Mortality rate of $S$. recurvalis larvae $\left(L_{2}\right)$ fed on diet mixed with different concentrations of Dipel $2 X$ (B. thuringiensis kurstaki) in 7 days post treatment

\begin{tabular}{llllllll}
\hline Dipel 2 Concentration\% & \multicolumn{7}{l}{ Mortality \% at 7 days post treatment } \\
\cline { 2 - 8 } & 1 & 2 & 3 & 4 & 5 & 6 & 7 \\
\hline 5 & 0 & 44 & 100 & & & & \\
2.5 & 0 & 23 & 62 & 100 & & & \\
1.25 & 0 & 15 & 55 & 83 & 100 & & \\
0.6 & 0 & 12 & 44 & 64 & 88 & 91 & 92 \\
0.3 & 0 & 11 & 35 & 59 & 78 & 86 & 86 \\
Control & 0 & 0 & 0 & 0 & 0 & 0 & 0 \\
\hline
\end{tabular}

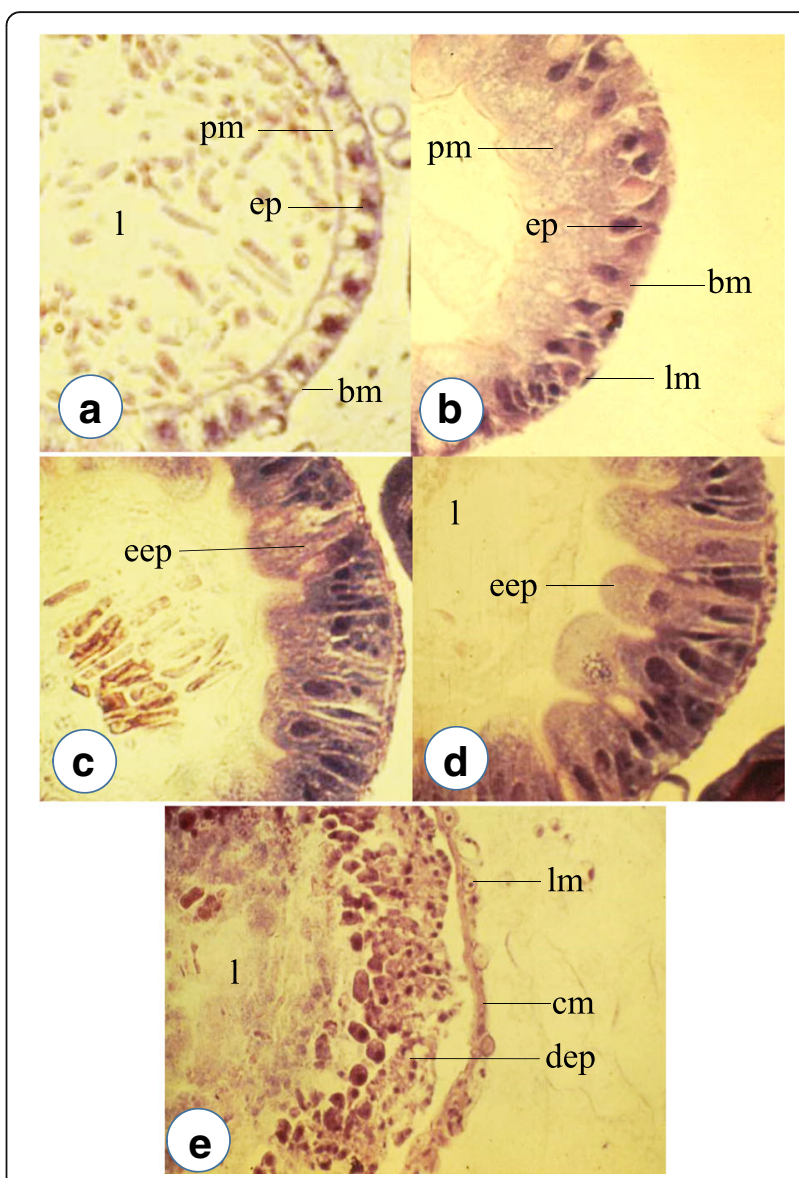

Fig. 2 Mid-gut structure after ingestion of B.t. a Control. b-e After 1, 2,3 , and 4 days from infection. (bm) basement membrane, $(\mathrm{cm})$ circular muscle, (dep) disintegrated epithelial cells, (ep) epithelial cell, (eep) elongated epithelial cell, (Im) longitudinal muscle, (I) lumen, (pm) peritrophic membrane

the diet mixed with B.t.k. (1.25\%), the peritrophic membrane became thicker and showed alterations on several locations of the mid-gut (Fig. 2b). Two days post treatment, the epithelial cells were clearly swollen showing an elongation (eep) toward the lumen (l), associated with vacuolization in the cytoplasm as shown in Fig. 2c. On the third day post treatment, the elongation of the mid-gut epithelial cells was progressed associated with separation of the cells from each other in many locations of the midgut (Fig. 2d) and also from the basement membrane. On the fourth day, cross sections in mid-gut of the infected larvae showed the epithelial cells extremely swollen, elongated, and detached from the basement membrane; thus, they were fallen in the lumen (l) of the mid-gut as a result of cell lyses. At the end, as the treated larvae died, all mid-gut cells showed a complete lyses, separated from each other and from the basement membrane as seen in Fig. 2e. These results are in line with those reported by Shen and Qian (1994) and recorded in other B.t. susceptible lepidopteran larvae described by El-Husseini (1976), 
Saad et al. (1985), Knowles and Ellar (1987), and Omar et al. (2005). These histopathological alterations in the architecture of larval mid-gut, when infected with B.t. endotoxin-spore-complex, are enhanced by the action of the delta endotoxin crystals (parasporal bodies). As the crystals reached the mid-gut, they were dissolved in the alkaline mid-gut lumen medium of the susceptible host larvae and were cleaved by the trypsin like enzymes into trypsin-resistant toxin molecules. The resulted toxin diffuses through the peritrophic membrane and binds to specific proteins of the brush-border membrane (Knowles and Ellar 1987; Wolfersberger 1992). This binding build cation-conducting pores, which disrupt the defence permeability of the peritrophic membrane. Saad et al. (1985), Rie-Van et al. (1990), and Wolfersberger (1992) stated that this driving force for amino acid uptake by the mid-gut cells was then removed, allowing the redistribution of cations between the mid-gut lumen and cell cytoplasm, and removing the force energizing maintenance of the 1000fold proton activity gradient across the apical membrane of mid-gut cells; and this mechanism caused a change in cytoplasmic properties great enough to disrupt normal cell metabolism, and led to the above described symptoms (Fig. 2) that ended by death of the infected larvae. The present findings are in agreement with those of Dimitriadis and Domouhtsidou (1996) who pointed out that increasing the doses of B.t. would result in increasing the percentage of lepidopteron larval mortality.

\section{Conclusion}

The commercial microbial bioinsecticide Dipel 2X (Bacillus thuringiensis kurstaki) was tested against the 2nd instar larvae $\left(\mathrm{L}_{2}\right)$ of the beet web moth, Spoladea recurvalis $\mathrm{F}$., reared on a semi-synthetic diet under laboratory conditions. Cross sections in the mid-gut examined by a light microscope showed gradual alterations in mid-gut structure till death of the treated larvae.

\section{Acknowledgement}

Not applicable.

\section{Consent of publication}

I agree to publish this scientific paper in the EJBPC.

\section{Author's contribution}

I have written, read, and approved the manuscript.

\section{Funding}

This work was not supported by any funding body, but personally financed.

\section{Availability of data and materials}

All data are available in the manuscript and the materials used in this work are of high transparency and grade.

\section{Competing interest}

The author declares that he has no competing interest.

Ethics approval and consent to participate

I agree to all concerned regulations.
Received: 19 March 2019 Accepted: 14 August 2019

Published online: 24 August 2019

\section{References}

Dimitriadis VK, Domouhtsidou GP (1996) Effect of Bacillus thuringiensis strain Ormylia spore-crystal complex on mid-gut cells of Dacus oleae larvae. Cytobios. 87(348):19-30

El Husseini MM (2015, October 2015) The history of biological control in Egypt: past, present and future. $4^{\text {th }}$ International Conference of Bio-friendly Applied Biological Control of Agricultural Pests and Phytopathogens. Cairo - Egypt:19-22

El Husseini MM, Agamy EA, Mesbah AH, Ola O, El-Fandary, M.F A (2008) Using Beauveria bassiana (Bals.) Vuillemin in spraying and dusting applications for biological control of sugar beet insect pests in Egypt. Egypt. J. Biol. Pest Control 18(2):369-375

El-Husseini MM (1976) Control of the leaf-roller pests in apple orchards using Bacillus thuringiensis Berliner. Ph. D. Thesis, Humboldt- University of Berlin, Germany, pp.120

El-Husseini MM (1980) A nuclear polyhedrosis virus inducing cellular hypertrophy in larvae of Spodoptera exigua (Hb.). Proc.1st Conf. Plant Protection Inst.,Vol.Il: 405-419

El-Husseini MM (2006) Microbial insect pest control: is it an effective and environmentally safe alternative? Ninth Arab Congress of Plant Protection, 1923 November, 2006. Damascus, Syria

El-Husseini MM, Agamy EA, Mahmoud BA, Ibrahim RFS (2012) Effect of Bacillus thuringiensis kurstaki on larvae of the spiny bollworm, Earias insulana (Boisd.) (Lepidoptera: Arctidae). Egypt. J. Biol. Pest Control 22(1):67-72

Figueroa F, Gonzalez RAL, Semidey N, Gonzales L (2005) Feeding preference of the sugar beet webworm (Spoladea recurvalis F.) (Lepidoptera: Pyralidae) for Trianthema portulacastrum L. (Aizoaceae) and other putative hosts in Puerto Rico. Journal of Agriculture of the University of Puerto Rico 89(3/4):211-219

Knowles, B. H. and Ellar, D. J. 1987. Cooloid-osmotic lyses is a general feature of the mechanism of action of Bacillus thuringiensis $\delta$ - endotoxin with different insect specificity. Biochemica et Biophysica Acta (G), General subjects, 924: 509-518.

Mureithi DM, Fiaboe KKM, Ekesi S, Meyhöfer R (2017) Important arthropod pests. on leafy Amaranth (Amaranthus viridis, A. tricolor and A. blitum) and broadleafed African nightshade (Solanum scabrum) with a special focus on hostplant ranges. Afr. J. Hort. Sci. 11:1-17

Omar, Naglaa A. M., 2004. Impact of Bacillus thuringiensis on some biological, histological, and physiological aspects of Galleria mellonella L. as a susceptible host. Ph. D. Thesis, Faculty of Agriculture, Cairo University; pp.148.

Omar NAM, El-Husseini and MM, El-Bishry MH (2005) Histopathological changes in larvae of the Greater Wax Moth, Galleria mellonella L. caused by Bacillus thuringiensis kurstaki. Egypt J. Biol. Pest Control 15(1):35-40

Reda FM, Hassanein WA, Sherif EAH, Shahera M (2016) Toxicological studies and field applications of anew Bacillus thuringiensis isolate (Bt1) and two chemical pesticides on Spodoptera littoralis (Boisd.) (Lepidoptera: Noctuidae). Egypt J. Biol. Pest Control 26(2):229-236

Rie-Van J, Jansens S, Hofte H, Degheele D, Mellaert H (1990) Receptors on the brush border membrane of the insect mid-gut as determinant of the specificity of Bacillus thuringiensis delta endotoxin. App. \& Environ. Microbiol. 56(5):1378-1385

Saad, A. S. A.; Elewa, M. A.; Zagloul, O. A.; Awad, H. A. and Masoud, M. A., 1985. Toxicological and histopathological studies on spiny bollworm (Earias insulana). Mededelingen van de Faculteit Landbouwwetenschappen Rijksuniversiteit, Gent, 50 (2b): 735-750.

Shen JZ, Qian CF (1994) Effects of sublethal dosages of Bacillus thuringiensis subsp. galleriae on the activities of phosphatases in Galleria mellonella larvae. Acta Agriculturae Universitatis Pekinensis 20(3):276-280

Shorey HH, Hale RL (1965) Mass rearing of the larvae of nine noctuid species on a simple artificial medium. J.Econ.Entomol. 58:522-524

Sithanantham, S., Matoka, C.M., Maundu, M., Jakari, M., Agong, S.G. 2003. Integrated crop protection research for sustainable production of Indigenous vegetable crops in Eastern Africa. Proceedings of $4^{\text {th }}$ Horticultural Seminar on Sustainable Horticultural production in the Tropics held in Njoro, Kenya.

Wolfersberger MG (1992) V-ATPase-energized epithelia and biological insect control. J. Exp. Biol. 172:377-386

\section{Publisher's Note}

Springer Nature remains neutral with regard to jurisdictional claims in published maps and institutional affiliations. 